音声言語医学 $56: 321-325,2015$

原著

\title{
吃音を意識した年齢に関する検討
}

\author{
菊池 良和 ${ }^{11}$ 梅㟝 俊郎 ${ }^{2,3)}$ 安達 一雄 ${ }^{1)}$ \\ 山口 優実 ${ }^{1)}$ 佐藤 伸宏 $^{2}$ 小宗 静男 ${ }^{1)}$
}

\begin{abstract}
要 約：「吃音を意識させないように」「親子で吃音のことを話さない」ことが正しい対応だ と思われている現状がある。しかし，自分に吃音があることを意識する年齢やその場面につい ての詳細な報告はこれまでにない，そこで 10 歳以上の吃音者で親が一緒に来院した 40 組に対 して, 吃音に気づいた年齢の違いを調べた。吃音者本人の意識年齢は平均 8.1 歳 (3〜16 歳)だっ た。自分に吃音があると気づいた場面として,「親との会話中」はわずか $8 \%$ であり,「園や学校」 で気づいたのは $57 \%$ だった。また，親が子どもの吃音に気づいた年齢は 5.3 歳（2１4 歳）で, ほとんどの症例で親のほうが先に吃音の発症に気づいていた，以上より，多くの親は子どもに 吃音を意識させることはなかったが，園・学校など人前での発表・会話で，本人は吃音を意識 し始めたことがわかった、吃音に伴ういじめやからかいなどの不利益を最小限にするためには, 吃音の話題を親子でオープンに話す必要があると示唆された.
\end{abstract}

索引用語：吃音, 意識, 親, からかい・いじめ

\section{Awareness Ages and Situations of People who Stutter}

\author{
Yoshikazu Kikuchi ${ }^{1)}$, Toshiro Umezaki ${ }^{2}{ }^{3)}$, Kazuo Adachi', Yumi Yamaguchi', \\ Nobuhiro Sato ${ }^{2)}$ and Shizuo Komune ${ }^{1)}$
}

\begin{abstract}
It is commonly believed that the correct response of parents of children who stutter is to avoid making the child aware of stuttering and not discuss the issue of stuttering with the child. However, there are few detailed reports concerning the awareness ages and situations of people who stutter (PWS) and their parents. We asked 40 pairs of PWS (minimum age: 10 years) and their parents about the time they first became aware of stuttering. The average age of awareness of stuttering in PWS was 8.1 years. Only 8 percent became aware of their situation in talking with their parents, while 57 percent stated their awareness traced to preschool or school days. Moreover, most parents noticed their child's stuttering earlier than their child, and the children became aware only after they encountered situations at school where they had to speak with or before others. In order to minimize the negative ramifications of stuttering such as teasing and bullying, parents need to talk frankly to their children about their stuttering.
\end{abstract}

九州大学医学研究院耳鼻咽唉科学 ${ }^{11} ：$ ₹ 812-8582 福岡市東区馬出 3-1-1

福岡山王病院音声・曣下センター2)： ₹814-0001 福岡市早良区百道浜 3-6-45

国際医療福祉大学 ${ }^{3)}$ : $\overline{7} 814-0001$ 福岡市早良区百道浜 1-7-4

${ }^{11}$ Department of Otorhinolaryngology, Kyushu University: 3-1-1 Maidashi, Higashi-ku, Fukuoka 812-8582, Japan

${ }^{2}$ Voice and Swallowing Center, Fukuoka Sanno Hospital: 3-6-45 Momochihama, Sawara-ku, Fukuoka 814-0001, Japan

${ }^{3}$ Internatlonal University of Health and Welfare: 1-7-4 Momochihama, Sawara-ku, Fukuoka 814-0001, Japan

2014 年 11 月 3 日受稿 2015 年 3 月 4 日受理 
Key words: stuttering, awareness, parents, teasing and bullying

\section{はじめに}

吃音症は 2〜 5 歳の間に, 人口の約 $5 \%$ に発症し ${ }^{1)}$, 発症 4 年で $74 \%$ 自然回復する疾患である ${ }^{2)}$ ，その高い 自然回復率のために，親だけではなく，多くの医療者 が治ることを切望してしまう。だ，実際には成人に なっても，世界中どこでも人口の $1 \%$ は吃音者が存在 するのである ${ }^{3)} .2014$ 年現在でも, 吃音の相談を受け ると、「親が子どもに吃音を意識させない」「親子で吃 音のことを話さない」という誤った対応をしている所 があると聞く

この日本の現状に大きく影響を及ぼしたと考えられ るのは, 日本がアメリカの吃音臨床を取り入れたこと が一因であろう。世界的に有名な吃音臨床家である ジョンソンは,「吃音治療とは, 親は子どもの吃音が 始まったと気づいても，それを意識させないように， 子どもがどもっていても，叱ったり，指摘をしないこ とである」と伝えている ${ }^{4,5)}$. この「意識させない」 という考え方により，ことばの相談室でも本人の前で 吃音のことを話さない「暗黙の了解（吃音の話題を夕 ブー化) 」6) や，本人が「どうして，ボクは同じ言葉を 繰り返すの? 」という素朴な疑問を親に投げ掛けても, 親が子どもと向き合って考えられない弊害が生じてい る.

そこで, 本研究の目的は, 本人が記憶に残っている 吃音を意識した年齢と場面が，親が意識した年齢と関 係があるか調べた。

\section{方法}

2011 年 3 月から 2014 年 10 月まで, 当科を受診し た吃音症患者 166 名のうち, 10 歳以上の吃音者で親 が一緒に来院した 40 組を対象とした。吃音者の内訳
は, 男性は 31 名, 女性は 9 名, 平均 18.3 歳（10４6 歳） だった。

対象者の吃音者本人には「ことばがつっかえるのに, 気づいたのは何歳ですか？」「どんな場面でしたか？」 の記述式質問を行った。また，親に対しては，「吃音 に初めて気づいたのは, いつですか?」という記述式 質問を行った。統計解析は JMP ${ }^{\circledR} 11$ (SAS Institute Inc., Cary, NC, USA）を用い， $\chi^{2}$ 検定を行った。

\section{結果}

図 1 に本人と親の吃音を意識した年齢の分布を示 す。親が吃音に気づいた年齢で最も多かったのは 3 歳 の就学前であるのに対して，本人が吃音であることを 意識し出した年齢は 7 歳 (小学校 1 年生)が最も多かっ た。吃音者本人の意識年齢の平均は 8.1 歳（3〜16 歳） であり, 親が吃音に気づいた年齢の平均は 5.3 歳 $(2$ 〜14 歳)であった。親子で意識年齢が一致した組は, 40 組中 11 組 (28\%) であり, 親と子の意識年齢の差 は 2.7 歳だった。

表 1 では, 就学前と就学後で意識した人数で分ける と, 統計学的に有意に親は就学前で気づくことが多く, 本人は就学後で吃音を意識することがわかった（ $\mathrm{p}<$ 0.05).

図 2 では, 本人が意識した状況だが, 親との会話で 吃音を意識した例は 3 名（8\%）しかいなかった。具 体的に覚えていない人が 14 名（35\%）であり，一番
表 1 本人と親の吃音の意識時期の違い

\begin{tabular}{ccc}
\hline & 本人 & 親 \\
\hline 就学前 & 11 人 & 28 人 \\
就学後 & 29 人 & 12 人 \\
\hline & & $\chi^{2}$ 検定 $\mathrm{p}<0.05$
\end{tabular}

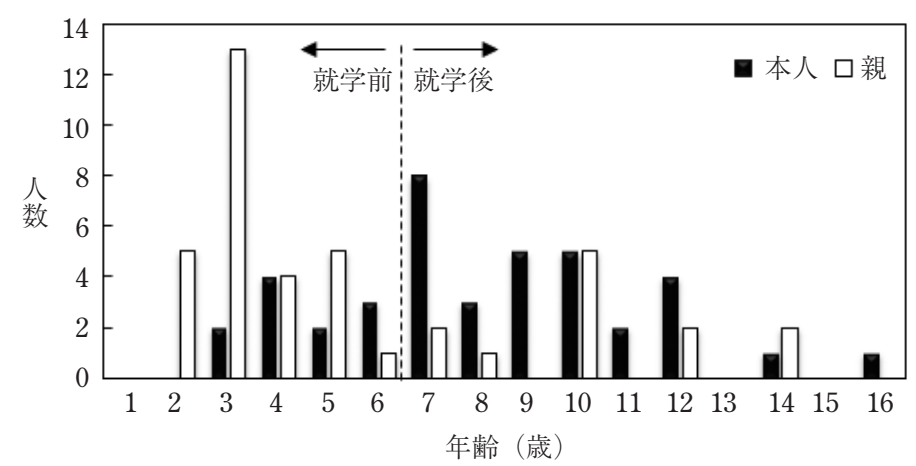

図 1 本人と親の意識年齢の分布 


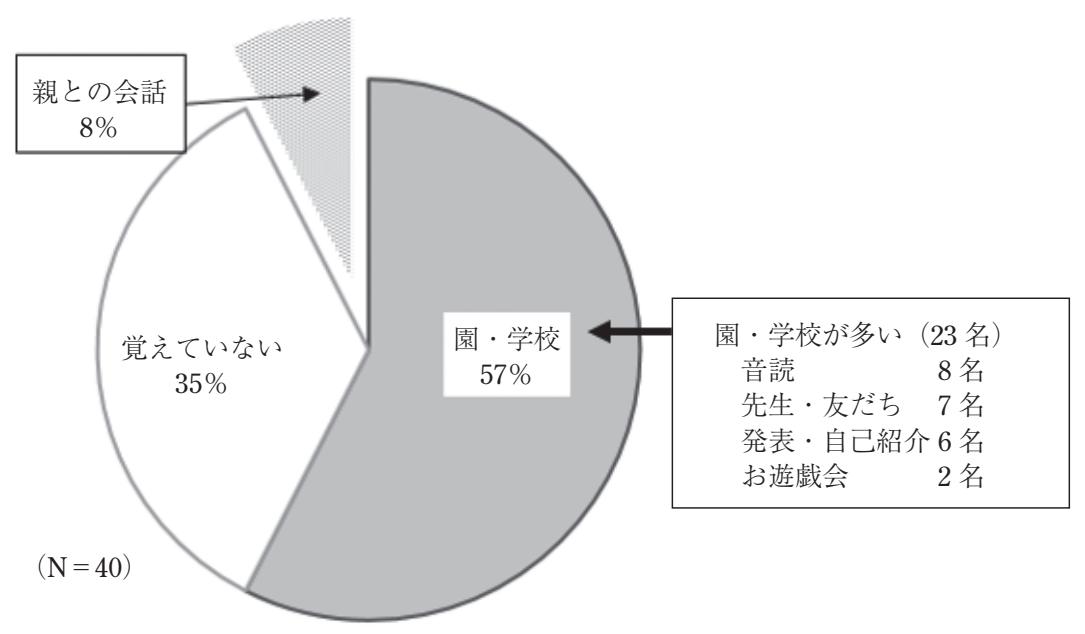

図 2 いつ吃音を意識したか？（本人）

表 2 本人が先に気づいたケース

\begin{tabular}{lcc}
\hline & 吃音の意識年齢 & いつ (場面) \\
\hline 18 歳, 男性 & 本人 7 歳 $<$ 親 12 歳 & 友だちとの会話 \\
17 歳, 女性 & 本人 8 歳 $<$ 親 10 歳 & 友だちとの会話 \\
28 歳, 男性 & 本人 11 歳 $<$ 親 14 歳 & 学校での音読 \\
\hline
\end{tabular}

多かったのは，園・学校が 23 名（57\%）だった。園・ 学校の具体的な内訳は, 音読のときが 8 名, 先生・友 だちとの会話 (指摘) が 7 名, 発表・自己紹介が 6 名, お遊戯会が 2 名だった。

表 2 に示すように，本人が親よりも早く気ついてい た例は 3 名ほどあった. 18 歳の男性は 7 歳時の友だ ちとの会話で気づいていたが, 親は 12 歳から吃音が 始まったと思っていた。1 17 歳の女性も同様に 8 歳時 に友だちとの会話で気づていたが，親は10 歳から 吃音が始まったと思っていた。28歳の男性は, 11 歳 の学校の音読時に吃音を意識したが，親は 14 歳から 吃音が始まったと思っていた。

\section{考察}

本研究の結果により, 以下の 2 点がわかった。 (1)多 くの場合, 親が子どもに吃音を意識させるのではなく, 園・学校などの人前での発表・会話によって，本人は 吃音を意識し始めていた。(2)本人および親の記憶にあ る吃音を意識し始めた年齢を聞いても，実際の発症年 齢とは異なる可能性がある.

1つ目の考察として，吃音を意識した場面が，親と

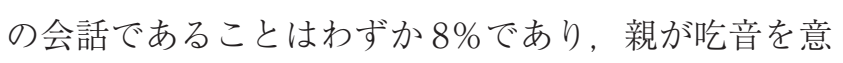
識させている行動は思ったより少なく，園・学校での 音読, 先生・友だちとの会話 (指摘), 発表·自己紹介,
お遊戯会に伴い自分の吃音を意識するようになったこ とがわかった。最初に意識したときは，からかい・い じめが生じていないかもしれないが, この音読, 先生・ 友だちとの会話 (指摘), 発表・自己紹介, お遊戯会 (劇) は，すべて小中高校生で吃音児が苦手とする場面であ る7). そして, 会話および人前で話す場面において, 真似され,「なんでそんな話し方するの? 」と指摘され， どもったら笑われるという 3 つの周囲の人からの反応 が吃音のからかい・いじめの初期状態となる ${ }^{8)}$. 吃音 のある子は, 約 $60 \%$ でかかい・いじめを経験する との報告があり ${ }^{9)}$, 当院通院吃音者でも同程度の確率 でからかい・いじめを経験している。

2013 年 6 月 28 日に公布された「いじめ防止対策推 進法」(法律第七十一号) では,「いじめ」は児童等が 心身の苦痛を感じているものと定義されている10). ま た，「からかい」とは，からかわれた子どもが傷づか ないこととしているが11),「からかい」と「いじめ」 の定義はさまざまであるために, 本論文ではからかい. いじめと一括りにしている。

「いじめ防止対策推進法」には，4いじめの防止等 に関する措置（二）いじめに対する措置（第二三条 関係）に,「(1）学校の教職員, 地方公共団体の職員 その他の児童等からの相談に応じる者及び児童等の保 護者は，児童等からいじめに係る相談を受けた場合に おいて，いじめの事実があると思われるときは，いじ めを受けたと思われる児童等が在籍する学校への通報 その他の適切な措置をとることとした」という記載が あり ${ }^{10)}$, 保護者および相談に応じる者は学校に知らせ ることが，いじめ防止につながる。

子どもが真似されたり，指摘されたり，笑われたり 
嫌な思いをしているのに，「吃音を意識させないよう に」と子どもと吃音の話をしたことがない親子が多く， 不登校に陥ってから相談に来るケースがある。今回の 研究から, 小学校 1 年生の頃に吃音を意識することが 一番多いために, 最低でも小学校に入学しても吃音が ある子には，吃音に伴うからかい・いじめ（真似，指 摘，笑い）が起きていないか確認し，もし起きている のであれば，学校の先生と相談して，からかい・いじ めの予防に努めることが必要であろう ${ }^{12)}$.

「吃音治療は，吃音を意識させないように」という 方針を示したジョンソンは，吃音原因論として 1940 〜1960 年代に「診断起因説」を提唱した。 それは, 子どもの非流暢な発話を, 親が「吃音」と気づき, 本 人に意識させることにより，吃音が始まる，という吃 音の原因は環境因子が 100\% であるという仮説による

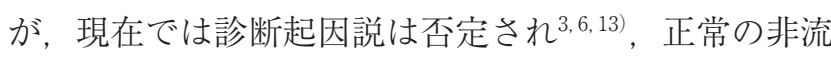
暢性に否定的な言葉掛けをしても吃音は生じなかった ことが報告されている ${ }^{14)}$ また，吃音があったことを 覚えていても，全く治療しなくても治った 15 人もの 吃音者の報告もある ${ }^{15)}$.「意識させると治らない」と いうことは正しい対応ではないだろう.

意識することが, 吃音の悪化につながらないのは, メ夕言語意識の研究から示唆されている. 非流暢性(音 節の繰り返し）に対してメ夕言語意識を調べた研究で は, 3 歳, 4 歳ではそれぞれ，15\%，30\%と低かったが, 5 歳では $80 \%$ ，6歳では $100 \%$ であった ${ }^{16,17)}$ 。つまり, 発話の流暢性に対するメ夕言語意識をもつ割合は 3 4 歳では低く, 5〜6 歳では著しく高くなる。しかし, 定型発達児の発話に抢ける非流暢性は 4 歳から, メ夕 言語意識が高まる 5 歳にかけて減少するのであ る $^{18,19)}$.

2 つ目の考察として, 10 歳以上の吃音者本人と親に 吃音を意識した年齢を聞くことにより，親は就学前の 平均 5 歳, 本人は平均 8 歳頃に意識した記憶が残って いることがわかった. 親子で意識年齢が一致した組は, 40 組中 11 組（28\%）であるために，より近い発症年 齢を確認するには，親と本人の両者の意識した年齢を 総合して考慮する必要があることがわかったＹＹａiri らは 163 名の吃音の発症の様式を急に発症する（1～3 日）タイプと, 徐々に発症するタイプ (3 週間以上), その中間タイプ（1２週間）の 3 つに分類し，その 割合は $41 \% ， 27 \% ， 32 \%$ であったことを報告した ${ }^{20)}$. 急に発症する夕イプが最も多いが， 3 週間以上掛けて 親が吃音を認識するケースもあり，表 2 のように親の 知らない場面で起こり，本人も親に相談しないケース
もあったのだろう。

利益相反自己申告：申告すべきものなし，

本研究は, 日本学術振興会科学研究費, 平成 24 年一平成 26 年若手研究 (B) 25861566, 代表者菊池良和の資金を用いて遂 行した.

\section{文献}

1) Månsson H: Childhood stuttering: Incidence and development. J Fluency Disord, 25: 47-57, 2000.

2) Yairi E and Ambrose NG: Early childhood stuttering I: persistency and recovery rates. J Speech Lang Hear Res, 42 (5): 1097-1112, 1999.

3) Bloodstein $\mathrm{O}$ and Bernstein Ratner N: A Handbook on Stuttering, 6th ed, Thomson Delmar Learning, NY, 2008.

4) Johnson W: A study of the onset and development of stuttering. Stuttering in Children and Adults, University of Minnesota Press, Minneapolis, 1955.

5) Saltuklaroglu $T$ and Kalinowski J: How effective is therapy for childhood stuttering? Dissecting and reinterpreting the evidence in light of spontaneous recovery rates. Int J Lang Commun Disord, 40 (3): 359374, 2005.

6）バリー・ギター著, 長澤泰子訳 : 吃音の基礎と臨床一統合 的アプローチ, 学苑社, 東京, 2007.

7）見上昌睦, 森永和代：吃音者の学校教育期における吃音の 変動と通常の学級の教師に対する配慮・支援の要望. 聴覚 言語障害, 34 (3)：61-81, 2006.

8）菊池良和：吃音のリスクマネジメント, 学苑社, 東京, 2014.

9) Langevin M, Bortnick K, Hammer T, et al: Teasing/ bullying experienced by children who stutter: Toward development of a questionnaire. Contemp Issues Commun Sci Disord, 25: 12-24, 1998.

10）文部科学省：いじめ防止対策推進法（平成 25 年法律第 71 号), 2013.

11）町田市教育委員会：いじめ対応マニュアル (改訂版)「守る」 「気付く」「防ぐ」, 2013.

12）見上昌睦：【吃音治療の展望】吃音巟に対する通常の学級 の教師，保育所の保育士による配慮および支援．コミュニ ケーション障害学, 25 (2) : 156-163, 2008.

13) McDearmon JR: Primary stuttering at the onset of stuttering: a reexamination of data. J Speech Hear Res, 11 (3): 631-637, 1968.

14) Ambrose NG and Yairi E: The Tudor study: Data and ethics. Am J Speech Lang Pathol, 11 (2): 190-203, 2002.

15) Finn P, Howard R and Kubala R: Unassisted recovery from stuttering: self-perceptions of current speech behavior, attitudes, and feelings. J Fluency Disord, 30 (4): 281-305, 2005.

16）伊藤友彦: 構音, 流暢性に対するメ夕言語知識の発達. 音 声言語医学, $36: 235-241,1995$.

17）伊藤友彦：メ夕言語意識の発達研究と言語臨床 : 音韻面を 中心に.コミュニケーション障害学, 26 (2)：83-94, 
2009.

18）伊藤友彦：幼児の発話における非流暢性と言語習得との関 係. 音声言語医学, $23: 211-220,1982$.

19）伊藤友彦：3歳から 6 歳にかけての発話における非流暢性 の変化と文構造の習得一縦断研究—. 音声言語医学, 24 : 248-256, 1983.

20) Yairi E and Ambrose N: Chapter 3 The onset of stuttering. Early Childhood Stuttering for Clinicians by Clinicians, Pro-Ed Inc, Austin, pp 57-61, 2005.

別刷請求先 : 干 812-8582 福岡市東区馬出 3-1-1 九州大学医学研究院耳鼻咽喉科学 菊池良和 